\title{
Biodiversity of Chilean sea anemones (Cnidaria: Anthozoa): distribution patterns and zoogeographic implications, including new records for the fjord region*
}

\author{
Verena Häussermann \\ Fundación Huinay, Departamento de Biología Marina, Universidad Austral de Chile \\ Casilla 567, Valdivia, Chile
}

\begin{abstract}
The present paper provides a complete zoogeographical analysis of the sea anemones (Actiniaria and Corallimorpharia) of continental Chile. The species described in the primary literature are listed, including depth and distribution records. Records and the taxonomic status of many eastern South Pacific species are doubtful and need revision and confirmation. Since 1994, we have collected more than 1200 specimens belonging to at least 41 species of Actiniaria and Corallimorpharia. We sampled more than 170 sites along the Chilean coast between Arica (18 $30^{\circ} \mathrm{S}$,

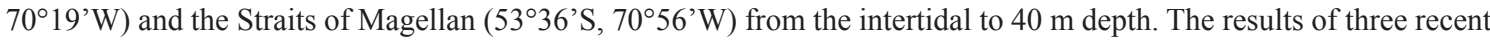
expeditions to the Guaitecas Islands $\left(44^{\circ} \mathrm{S}\right)$ and the Central Patagonian Zone $\left(48^{\circ}-52^{\circ} \mathrm{S}\right)$ are included in this study. In the fjord Comau, an ROV was used to detect the bathymetrical distribution of sea anemones down to $255 \mathrm{~m}$. A distribution map of the studied shallow water sea anemones is given. The northern part of the fjord region is inhabited by the most species (27). The results show the continuation of species characteristic for the exposed coast south of $42^{\circ} \mathrm{S}$ and the joining of typical fjord species at this latitude. This differs from the classical concept of an abrupt change in the faunal composition south of $42^{\circ} \mathrm{S}$.
\end{abstract}

Key words: distribution, zoogeography, benthos, Actiniaria, Corallimorpharia, Chile.

\section{Biodiversidad de anémonas de mar chilenas (Cnidaria: Anthozoa): patrones de distribución e implicaciones zoogeográficas, incluyendo nuevos registros para la región de los fiordos*}

RESUMEN. Se presenta un análisis zoogeográfico de las anémonas Actiniaria y Corallimorpharia de Chile continental. Se indican las especies registradas en la literatura existente, incluyendo un mapa con la distribución geográfica y datos sobre la distribución batimétrica. Numerosos registros y estatus taxonómicos de las especies del Pacífico suroriental son dudosos, y requieren revisión y confirmación. De 1994 a la fecha, se han obtenido más de 1.200 ejemplares pertenecientes a lo menos a 41 especies de Actiniaria y Corallimorpharia. Se analizaron más de 170 sitios, a lo largo de la costa chilena

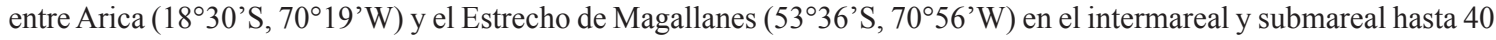
$\mathrm{m}$ de profundidad. Se incluyen resultados de dos expediciones recientes al archipiélago de las Guaitecas $\left(44^{\circ} \mathrm{S}\right) \mathrm{y}$ en la Zona Patagónica Central $\left(48^{\circ} \mathrm{S}-52^{\circ} \mathrm{S}\right)$. En el fiordo Comau se utilizó un ROV para detectar la distribución batimétrica de anémonas hasta los $255 \mathrm{~m}$. La zona norte de la región de fiordos chilenos presenta el máximo número de especies (27). Los resultados muestran la continuidad de especies características de costas expuestas al sur de $42^{\circ} \mathrm{S}$ y la agregación de especies típicas de los fiordos en esa latitud. Esto significa una diferenciación del concepto arraigado del cambio brusco en la composición de la fauna marina a partir de $42^{\circ} \mathrm{S}$.

Palabras clave: distribución, zoogeografía, bentos, Actiniaria, Corallimorpharia, Chile.

Corresponding author: Verena Häussermann (vreni_haeussermann@yahoo.de, vh@huinay.cl)

* Trabajo presentado en el XXV Congreso de Ciencias del Mar de Chile y XI Congreso Latinoamericano de Ciencias del Mar (COLACMAR), realizados en Viña del Mar, entre el 16 y 20 de mayo de 2005. 


\section{INTRODUCTION}

Although sea anemones are very abundant along the Chilean coast, they are among the most neglected groups of benthic invertebrates; very little information is available on these species, especially for the Central Patagonian Zone $\left(46^{\circ}-54^{\circ} \mathrm{S}\right)$. The majority of the 63 species cited for continental Chile has been described from material collected during large vessel-based expeditions to the eastern South Pacific and Antarctica during the 19th and first half of the 20th century (Lesson, 1830; Dana, 1846; Hertwig, 1882; McMurrich, 1893, 1904; Carlgren, 1899 (for 1898), 1927, 1959). Many species have not been cited or studied since their first description. As the original descriptions are often very short, incomplete, based on poorly preserved material, and include few characteristics of the living animals (e.g. see Carlgren, 1959), identification of the species in the field is nearly impossible (Häussermann, 2004a). Only about a dozen papers with restricted topics have been published about Chilean sea anemones since then (Carter, 1965; Stotz, 1979; Brace, 1981; Zamponi \& Excoffon, 1992, 1995; Dayton et al., 1995; Häussermann \& Försterra, 2003; Häussermann, 2003, 2004b, $2004 c$ ), including only two new species (RiemannZürneck \& Gallardo, 1990; Häussermann \& Försterra, 2001). The sea anemones of the fjord region are the least studied; only two of the recent papers deal with one species of the fjords each (Dayton et al., 1995; Häussermann, 2004c). Sebens \& Paine (1979) published the first distribution map of 31 Chilean sea anemones. Häussermann \& Försterra (2005) compiled a species list of sea anemones described for the Chilean coast, presented a distribution map of 32 shallow water sea anemones, and discussed the relationship of the Chilean actinofauna with the Argentinean and Antarctic fauna.

Since 1997, Günter Försterra and I have collected sea anemones all along the Chilean coast. In 2005 and 2006, we first carried out three expeditions to the remote Guaitecas Islands $\left(44^{\circ} \mathrm{S}\right)$ and to the hardly accessible Central Patagonian Zone $\left(48^{\circ} \mathrm{S}-52^{\circ} \mathrm{S}\right)$. We also applied an ROV at 16 sites in the fjord Comau $\left(42^{\circ} \mathrm{S}\right)$. These additional data are included in a discussion of the latitudinal, longitudinal, and bathymetrical distribution patterns of sea anemones along the Chilean coast with a special focus on the fjord region.

\section{MATERIAL AND METHODS}

Studying the original literature, I compiled a list of all sea anemones (Actiniaria and Corallimorpharia) described for continental Chile, including family affiliation, original species name, type locality (if within Chile), and geographic and bathymetrical distribution (Table 1, Fig. 1). I compared the results to the data available in the hexacoral database (Fautin, 2003). Between 1994 and 2006, together with Günter Försterra, we observed, collected, examined, and preserved more than 1200 specimens of 41 clearly distinguishable shallow-water Actiniaria and Corallimorpharia at more than 170 sites along the Chilean coast from Arica $\left(18^{\circ} 30^{\prime} \mathrm{S}, 70^{\circ} 19^{\prime} \mathrm{W}\right)$ to Fuerte Bulnes, Straits of Magellan (53 $36^{\prime}$ 'S, $\left.70^{\circ} 56^{\prime} \mathrm{W}\right)$. The results of three recent expeditions to the Guaitecas Islands $\left(44^{\circ} \mathrm{S}\right)$ and the Central Patagonian Zone $\left(48^{\circ}-52^{\circ} \mathrm{S}\right)$ are included in this study. For details on sampling sites, see Häussermann (2003) and Försterra \& Häussermann (2003). We kept the distance between neighbouring study sites to less than $200 \mathrm{~km}$. We examined and photographed specimens in situ by means of Scuba-diving to depths of $25 \mathrm{~m}$ in northern and central Chile and to $35-40 \mathrm{~m}$ in the fjords. For details on the sampling, preservation, and examination processes of the samples, see Häussermann (2004a).

The biogeographic regions used in this study are based on the system proposed by Brattström \& Johanssen (1983) and Lancellotti \& Vásquez (1999).

\section{Biogeographic Provinces within Chile}

Most authors propose two main biogeographic regions within Chile: the Peruvian or warm-temperate Province between the Peninsula Illescas (or Bayovar) (approx. $6^{\circ} \mathrm{S}$ ) and Chiloé Island $\left(42^{\circ} \mathrm{S}\right)$ and the Magellan or cold-temperate Province between Chiloé Island and Cape Horn $\left(56^{\circ} \mathrm{S}\right)$ (Brattström \& Johanssen, 1983; Camus, 2001). Pickard (1973), Viviani (1979), and Stuardo \& Valdovinos (1992) suggested a subdivision of the Magellanic Province into a North Patagonian Zone $\left(42^{\circ} \mathrm{S}\right.$ to the Peninsula Taitao and Golfo de Penas, approx. $46.5^{\circ} \mathrm{S}$ ), a Middle or Central Patagonian Zone $\left(46.5^{\circ} \mathrm{S}\right.$ to the Straits of Magellan, approx. $53^{\circ} \mathrm{S}$ ), and a South Patagonian Zone (S of the Straits of Magellan). Lancellotti \& Vásquez (1999) negate the widely assumed faunal break at $42^{\circ} \mathrm{S}$ and propose a Transitional Temperate Region between $35^{\circ} \mathrm{S}$ and $48^{\circ} \mathrm{S}$, where a gradual but important change in the species composition occurs. 
Table 1. List of sea anemones described from the coast of continental Chile including original species names (in parentheses), synonymies with other Chilean species, and depth distribution within Chile and outside Chile (in parentheses). *: Species only occurring at depths of $100 \mathrm{~m}$ or deeper. ${ }^{\mathrm{E}}$ : endemic for Chile.

Tabla 1. Lista de especies de anémonas de la costa continental de Chile incluyendo nombre de especies originales (en paréntesis), sinónimos con otras especies chilenas y distribución batimétrica en o fuera de Chile (en paréntesis). *: Especies que viven bajo $100 \mathrm{~m}$ de profundidad. ${ }^{\mathrm{E}}$ : especies endémicas para Chile.

Order Corallimorpharia

Family Corallimorphidae Hertwig, 1882

Corynactis carnea Studer, 1879

Corynactis chilensis Carlgren, $1941^{\mathrm{E}}=$ ? C. carnea

*Corallimorphus profundus Moseley, $1877^{1}=$ C. antarcticus

Corallimorphus rigidus Moseley, $1877^{1}$

$0-79 \mathrm{~m}(100) \mathrm{m}$
$0-60 \mathrm{~m}(100) \mathrm{m}$
$2515 \mathrm{~m}(757-3704 ;$ Antarctic 30-40²) m
$3951 \mathrm{~m}(30-3700) \mathrm{m}$

Order Actiniaria

Suborder Endocoelantheae Carlgren, 1925

Family Halcuriidae Carlgren, 1819

*Halcurias pilatus McMurrich, $1893^{\mathrm{E}}$

$821 \mathrm{~m}(201-212) \mathrm{m}$

Suborder Nynantheae Carlgren, 1899

Tribe Athenaria Carlgren, 1899

Family Edwardsiidae Andres, 1881

Edwardsia intermedia McMurrich, 1893

Edwardsiella (Fagesia) ignota (Carlgren, 1959) ${ }^{\mathrm{E}}$

0-223 (300) m

40-60 m

Family Galatheanthemidae Carlgren, 1956

*Galatheanthemum profundale Carlgren, 1956

Family Halcampidae Andres, 1883

Cactosoma (Halianthus) chilensis (McMurrich, 1904) ${ }^{\mathrm{E}}$

Halcampa abtaoensis Carlgren, $1959^{\mathrm{E}}$

Family Halcampoididae Appellöf, 1896

*Scytophorus striatus Hertwig, $1882^{\mathrm{E}}$

Family Haloclavidae Verrill, 1899

Peachia chilensis Carlgren, $1934^{\mathrm{E}}$

Family Octineonidae Fowler, 1894

Octineon chilense Carlgren, $1959^{\mathrm{E}}$

$4209 \mathrm{~m}(6660-6720) \mathrm{m}$

$0 \mathrm{~m}$

$60 \mathrm{~m}$

$274 \mathrm{~m}$

in a large medusa

50-100 m

Tribe Thenaria Carlgren, 1899

Subtribe Acontiaria Stephenson, 1935

Family Aiptasiidae Carlgren, 1924

?Aiptasia sp. McMurrich, 1904 (probably belongs to another species)

$$
=\text {. Anthothoe chilensis }
$$

Family Aiptasiomorphidae Carlgren, 1949

Aiptasiomorpha elongata Carlgren, $1951^{3}$

Family Hormathiidae Carlgren, 1932

* Actinauge chilensis Carlgren, $1959^{\mathrm{E}}$

*Amphianthus lacteus (McMurrich, 1893) ${ }^{4} \mathrm{E}$ ?

*? Chondrophellia (Actinauge) nodosa var. coronata (Verrill, 1883) 5

= p.p. ?Actinauge verrilli McMurrich, 1893

= Actinauge fastigata McMurrich, 1893

(probably another species sensu Carlgren, 1949)

(*)Hormathia (Phellia) pectinata (Hertwig, 1882)

$=$ ?Phellia spinifera Hertwig, $1882^{7}$

*Phelliactis pelophila Riemann-Zürneck, 1973

*? Stephanauge (Actinauge) nexilis (Verrill, 1883) ${ }^{5}$

Family Sagartiidae Gosse, 1858

Anthothoe (Actinia) chilensis (Lesson, 1830)

=? Sagartia (Actinia) nymphaea (Drayton in Dana, 1846)
? (Tumbes (approx. $37^{\circ} \mathrm{S}$ ), probably upper littoral

0-36 m

$100 \mathrm{~m}$

$821 \mathrm{~m}$

$1238 \mathrm{~m}(600-2448) \mathrm{m}$

(3808' $\left.\mathrm{S}, 7^{\circ} 53^{\prime} \mathrm{W}\right)$

(380' S, 755' $\mathrm{W}$ )

50-300 $\mathrm{m}^{6}$ ?, 269-675 m $1095 \mathrm{~m}\left(37.28^{\circ} \mathrm{S}, 53.87^{\circ} \mathrm{W}\right)$ 300-350 $\mathrm{m}^{8}$ (800-2700?) $\mathrm{m}$ $350 \mathrm{~m}(182-547 \mathrm{~m})$

$$
\text { 0-60 m }
$$

$\left(33^{\circ} \mathrm{S}, 71.6^{\circ} \mathrm{W}\right)$ 
Cereus (Sagartia) herpetodes (McMurrich, 1904) ${ }^{\mathrm{E}}$

Choriactis (Actinia) impatiens (Couthouy in Dana, 1846) ${ }^{\mathrm{E}}$

Choriactis (Sagartia) laevis (Carlgren, 1899)

?Actinothoe (Sagartia) lobata (Carlgren, 1899) ${ }^{\mathrm{E}}$

$=$ ? Metridium parvulum McMurrich, $1904^{\mathrm{E}}$

$=$ ?M. senile subsp. lobatum ${ }^{9}$

Phellia (Hormathia) exlex (McMurrich, 1904) ${ }^{\mathrm{E}}$

Subtribe Endomyaria Stephenson, 1921

Family Actiniidae Rafinesque, 1815

Anemonia alicemartinae Häussermann \& Försterra, 2001

= Actinia sp. (sensu Sebens \& Paine, 1979)

Anthopleura (Bunodes) hermaphroditica (Carlgren, 1899) E?

Bolocera occidua McMurrich, 1893

$=*$ ? B. kerguelensis Studer, 1879

**? B. (Polystomidium) patens (Hertwig, 1882) ${ }^{\mathrm{E}}$

Boloceropsis platei McMurrich, $1904^{\mathrm{E}}$

Bunodactis (Cribrina) hermaphroditica (McMurrich, 1904) ${ }^{\mathrm{E}}$

Bunodactis (Bunodes) octoradiata (Carlgren, 1899)

$=$ ? p.p. Parantheopsis cruentata

Condylanthus magellanicus Carlgren, $1899^{11}$

?Bunodactis (Cribrina) elongata (McMurrich, 1904) ${ }^{\mathrm{E}}$

(probably belongs to another species)

?Bunodactis (Cystiactis) eydouxii (Milne Edwards, 1857) ${ }^{\mathrm{E}}$

(probably belongs to another species)

Epiactis georgiana Carlgren, 1927

?Gyrostoma incertum McMurrich, $1904^{\mathrm{E}}$

* Isosicyonis alba (Studer, 1879)

* Isotealia antarctica Carlgren, 1899

=*? Leiotealia badia McMurrich, $1893^{12 \mathrm{E}}$

Oulactis (Saccactis) coliumensis (Riemann-Zürneck \& Gallardo, 1990) ${ }^{\mathrm{E}}$

Oulactis (Metridium) concinnata (Drayton in Dana, 1846)

= Isoulactis chilensis Carlgren, 1959

Parantheopsis (Actinia) cruentata (Drayton in Dana, 1846)

Parantheopsis (Actinia) ocellata (Lesson, 1830)

$=$ ?Nemactis (Actinia) rubus (Drayton in Dana, 1846) ${ }^{\mathrm{E}}$

$=$ ? Actinia mertensii Brandt, $1835^{\mathrm{E}}$

Phymactis (Actinia) papillosa (Lesson, 1830) ${ }^{13}$

$=P$. clematis (Drayton in Dana, 1846)

$=$ ? Phlyctenactis tuberculosa sensu Zamponi \& Excoffon $1992(1995)^{14}$

Phymanthea (Actinia) pluvia Carlgren, 1959

Family Liponematidae Hertwig, 1882

*Liponema multipora Hertwig, $1882^{1}$

Subtribe Mesomyaria Stephenson, 1921

Family Actinoscyphiidae Stephenson, 1920

*Actinoscyphia (Actinernus) plebeia (McMurrich, 1893)

Family Actinostolidae Carlgren, 1932

Actinostola chilensis McMurrich, 1904

$=$ p.p. A. intermedia Carlgren, 1899

Actinostola (Dysactis) crassicornis (Hertwig, 1882)

*Anthosactis (Paractis) excavata (Hertwig, 1882) ${ }^{\mathrm{E}}$

Antiparactis (Actinia) lineolatus (Drayton in Dana, 1846) ${ }^{15}$

$=$ ?Pycnanthus lineolatus

Antholoba (Actinia) achates (Couthouy in Dana, 1846) $)^{13,16}$

*Ophiodiscus annulatus Hertwig, $1882^{\mathrm{E}}$

*Ophiodiscus sulcatus Hertwig, $1882^{\mathrm{E}}$

*Paranthus (Parantheoides) crassa (Carlgren, 1899)
0-22 m

$24 \mathrm{~m}(74-420 \mathrm{~m})$

$9 \mathrm{~m}\left(36.74^{\circ} \mathrm{S}, 73.13^{\circ} \mathrm{W}\right)$

7-35 m (Coquimbo; $\left.41.76^{\circ} \mathrm{S}, 73.14^{\circ} \mathrm{W}\right)$

? (upper littoral)

0-16 m

$0 \mathrm{~m}$

$45-223 \mathrm{~m}$

$(256-485 \mathrm{~m})$

$\left(3329 \mathrm{~m} ; 38.10^{\circ} \mathrm{S}, 88.03^{\circ} \mathrm{W}\right)$

$18-37 \mathrm{~m}$

$0-6 \mathrm{~m}, 80-225 \mathrm{~m}^{10}$

0-3 m

$36 \mathrm{~m}(-500) \mathrm{m}$

$20 \mathrm{~m}$

? (no locality)

50-60 (476) m

? (probably upper littoral)

$110(-360) \mathrm{m}$

$152-300(420) \mathrm{m}$

$143 \mathrm{~m}\left(53.10^{\circ} \mathrm{S}, 70.68^{\circ} \mathrm{W}\right)$

$20-45 \mathrm{~m}$

$0-15 \mathrm{~m}$

0-17 m

$0 \mathrm{~m}$ (low water)

$\left(33.00^{\circ} \mathrm{S}, 71.60^{\circ} \mathrm{W}\right)$

$\left(33.00^{\circ} \mathrm{S}, 71.60^{\circ} \mathrm{W}\right)$

$0-16 \mathrm{~m}$

0-16 m

450 m (219-2926 m)

$1238 \mathrm{~m}(1500-2402 \mathrm{~m})$

6-278 / 450? m

$18-278$ (320) m

$2515 \mathrm{~m}$

$0 \mathrm{~m}(-86) \mathrm{m}$

0-100 m (162 m)

$3951 \mathrm{~m}$

$2515 \mathrm{~m}$

? (110 m: Argentina) 
?Paranthus (Paractis) ignotus (McMurrich, 1904) =? P. niveus

? (probably upper littoral)

Paranthus (Actinia) niveus (Lesson, 1830)

Pseudoparactis (Paractis) tenuicollis (McMurrich, 1904) =? P. niveus

Suborder Prothantheae Carlgren, 1891

Family Gonactiniidae Carlgren, 1893

Gonactinia (Actinia) prolifera (Sars, 1835)

Suborder Ptychodacteae Stephenson, 1922

Family Preactiidae England in England \& Robson, 1984

Dactylanthus (Cystiactis) antarcticus (Clubb, 1908)

Species with uncertain classification (not in distribution map):

*Polyopis striata Hertwig, $1882^{\mathrm{E}}$

$3951 \mathrm{~m}\left(33.52^{\circ} \mathrm{S} ; 74.72^{\circ} \mathrm{W}\right)$

*? Aulorchis paradoxa Hertwig, $1888^{\mathrm{E}}$

Legend

Cosmopolitan species.

Riemann-Zürneck \& Iken, 2003.

Described from the Gulf of California.

Possibly also occurs in Argentina (Riemann-Zürneck, 1986).

A northern Atlantic species, the Chilean species might be a different one.

Dwarf species in shallow waters of the northern part of the fjord region (Carlgren, 1959).

Described from Argentina.

Argentinean species cited once for Chile (Doumenc, 1984).

Argentinean species (Riemann-Zürneck, 1986).

10 Since $B$. hermaphrodicica seems to be a shallow-water species, specimens from deep collection sites (Carlgren, 1959) might belong to another species.

11 A southern hemispheric species.

12 Described from the Straits of Magellan (McMurrich, 1893).

13 Many synonymies.

14 Described from Australia and New Zealand.

15 Outside Chile, cited once each for Panama and the Juan Fernandez Islands (McMurrich, 1893, 1904).

16 Widely distributed in South America and Scotia Arc.

?: dubious species

=?: uncertain/possible synonymy

\section{RESULTS}

\section{Literature review}

The literature review yielded the following results: 19 of the 70 species described for Chile are of uncertain taxonomic status, two of them are of uncertain classification, and seven could preliminarily be synonymized with other species (Actinauge fastigata, Phellia spinifera, Sagartia nymphaea, Metridium parvulum, Polystomidium patens, Nemactis rubus, Actinia mertensi) (Table 1). After excluding these synonymies, a list of 63 species of sea anemones described for the Chilean coast remains (Table 1): $19(30 \%)$ of these only occur in waters deeper than $100 \mathrm{~m}$ (see Table 1), one was once found in a medusa (Peachia chilensis), four are originally described from very distant regions (Chondrophellia nodosa var. coronata and its synonym Actinauge verrilli, Stephanauge nexilis, Phlyctenactis tuberculosa, and Aiptasiomorpha elongata), and three are cosmopolitan (Corallimorphus profundus, C. rigidus, and Liponema multipora).

Of the 63 species described in the literature for the Chilean coast, more than half are only mentioned in one publication for one (29 species) and three sampling sites (four species: Aiptasiomorpha elongata, Phelliactis pelophila, Gyrostoma incertum, Gonactinia prolifera), respectively. Four species (Oulactis coliumensis, Actinostola crassicornis, Choriactis impatiens, Boloceropsis platei) were only cited twice for Chile. Galanthemum profundale was found at only one Chilean sampling site, but is 

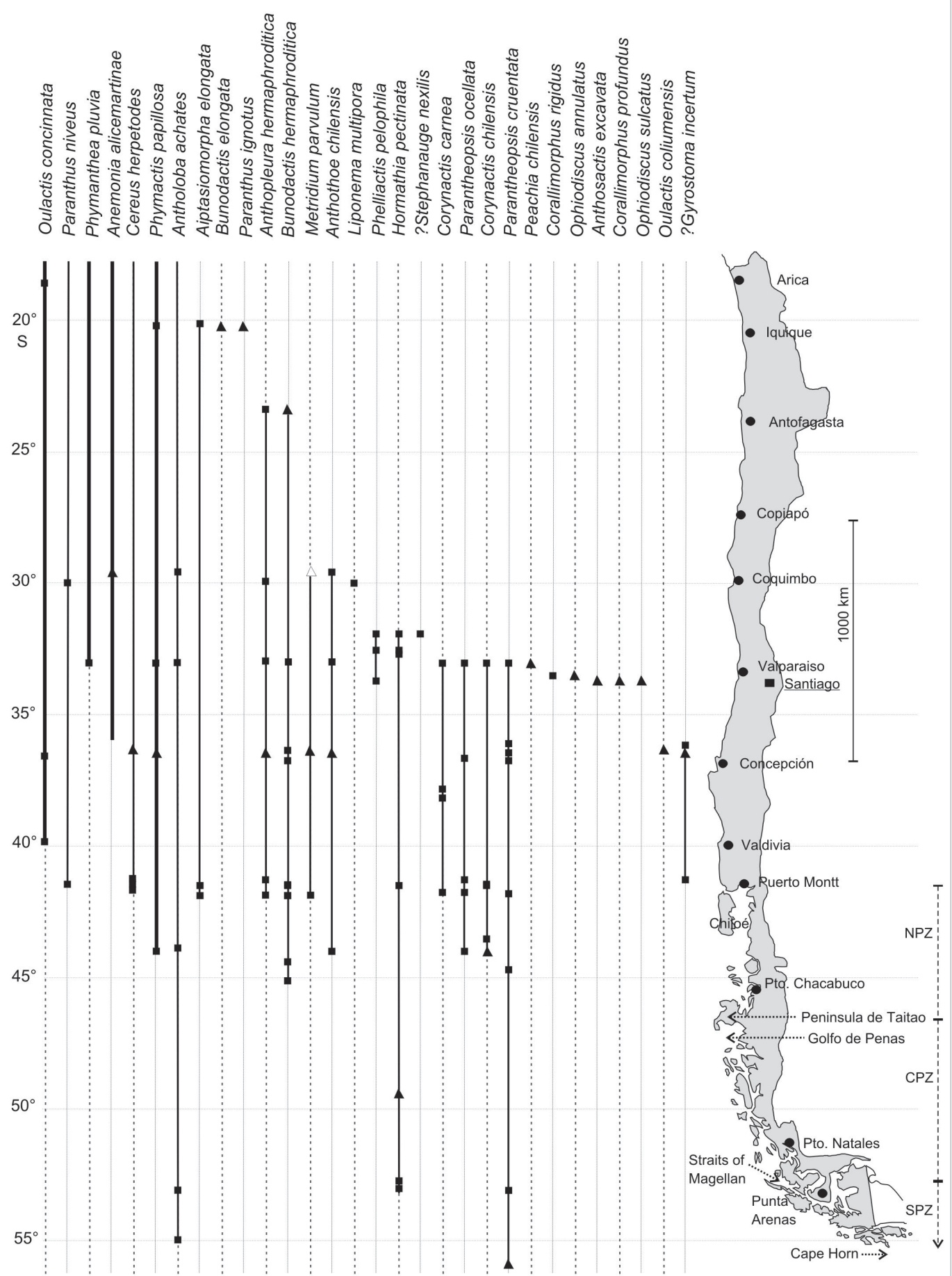

Figure 1a. Distribution map of 60 species of Chilean sea anemones according to the literature. The two species with doubtful classification and the species without location are not shown in the distribution map. $\Delta$ : type localities; $\Delta:$ type locality of synonymous species; $\square$ : other collection sites; collection sites are connected by lines for greater clarity. NPZ: North Patagonian Zone, CPZ: Central Patagonian Zone, SPZ: South Patagonian Zone.

Figura 1a. Mapa de distribución de 60 especies de anémonas chilenas según la literatura. Las dos especies con clasificación dudosa y la especie sin localidad no se muestran en el mapa. $\Delta$ : localidad tipo, $\Delta$ : localidad tipo de especies sinónimas, $\square$ : otros sitios de recolección, sitios de recolección están conectados por líneas para mayor claridad. NPZ: Zona Patagónica Norte, CPZ: Zona Patagónica Central, SPZ: Zona Patagónica Sur. 


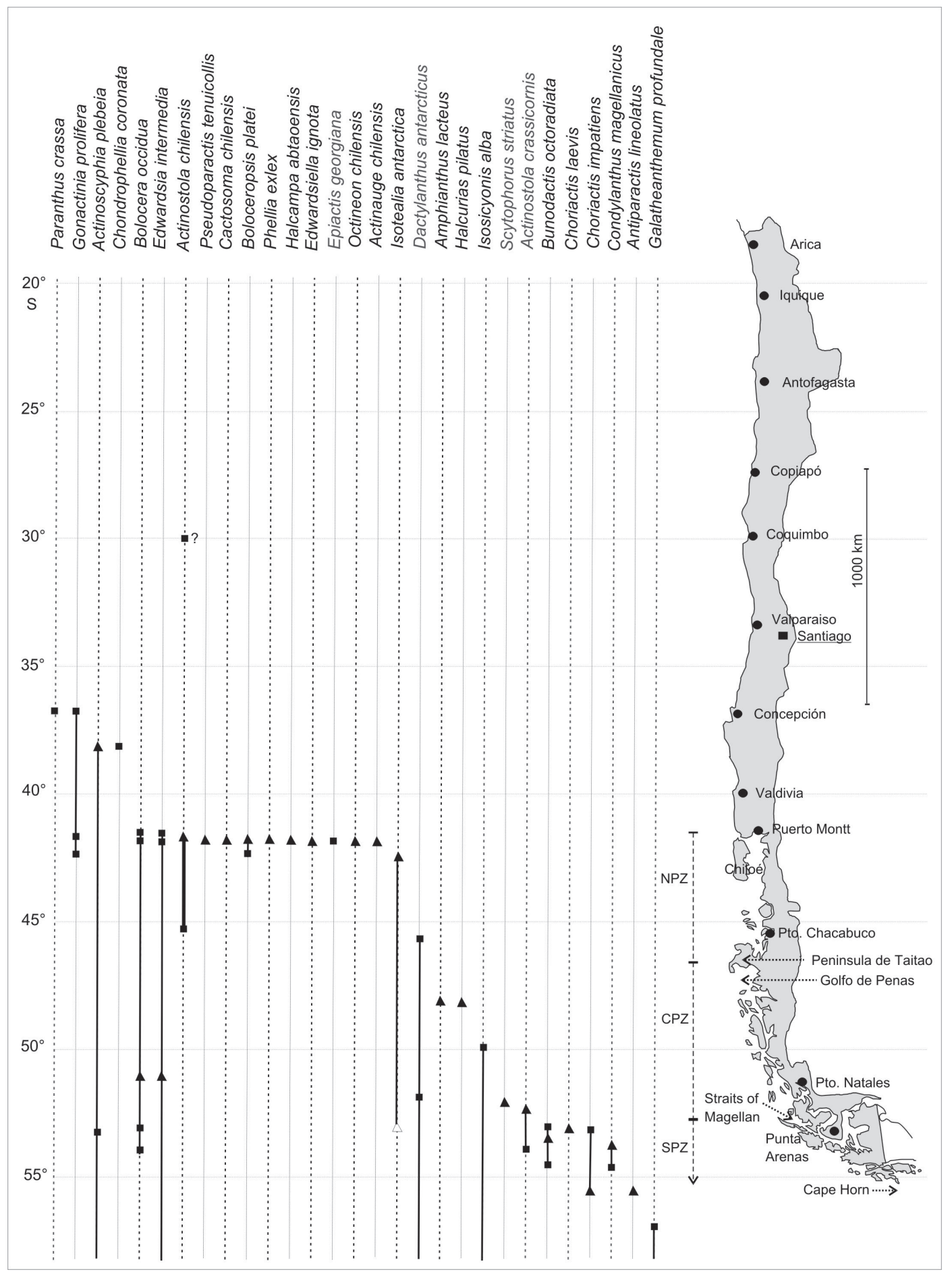

Figure 1b. Distribution map of 60 species of Chilean sea anemones according to the literature. The two species with doubtful classification and the species without location are not shown in the distribution map. $\Delta$ : type localities; $\Delta$ : type locality of synonymous species; $\square$ : other collection sites; collection sites are connected by lines for greater clarity. NPZ: North Patagonian Zone, CPZ: Central Patagonian Zone, SPZ: South Patagonian Zone.

Figura 1b. Mapa de distribución de 60 especies de anémonas chilenas según la literatura. Las dos especies con clasificación dudosa y la especie sin localidad no se muestran en el mapa. $\Delta$ : localidad tipo, $\Delta$ : localidad tipo de especies sinónimas, $\square$ : otros sitios de recolección, sitios de recolección están conectados por líneas para mayor claridad. NPZ: Zona Patagónica Norte, CPZ: Zona Patagónica Central, SPZ: Zona Patagónica Sur. 
widely distributed in the Subantarctic deep-sea. Of the 36 species mentioned only once for Chile, 19 are endemic.

I compiled a distribution map of 60 species (Figs. 1a y 1b), indicating the type (triangles) and other (quadrates) localities; all sites were connected by a line to improve clarity. Thirty-six species are described for the Peruvian Province $(17=47 \%$ restricted to it), 10 (28\%) of which are found at depths greater than $100 \mathrm{~m}$. Forty-two species are described for the Magellanic Province ( $24=57 \%$ restricted to it), eight (19\%) of which are described from deeper water; of these 42 species, 31 can be found in the North Patagonian Zone (four deep-water species), 10 in the Central Patagonian Zone (four deep-water species), and 16 in the South Patagonian Zone (four deep-water species).

\section{Own collection}

Of the 41 shallow-water sea anemone species (0-40 $\mathrm{m}$ ) we collected along the Chilean coast, we identified 23 to the species level and three to the genus level; 15 species have not been identified yet. I compiled a distribution map (Fig. 2) including findings from other authors.

Eighteen species inhabit the Peruvian Province ( $4=22 \%$ restricted to it) and 35 species the Magellanic Province ( $11=31 \%$ restricted to it). Of the 35 Magellanic species, 27 inhabit the North Patagonian Zone ( $7=26 \%$ restricted to this area), 19 the Central Patagonian Zone ( $5=26 \%$ restricted to this area), and eight the South Patagonian Zone ( $4=50 \%$ restricted to this area). There is no clear concentration of southern distribution limits. The highest concentration of the northern distribution limits lies at approx. $42^{\circ} \mathrm{S}(13)$.

Of the 18 Peruvian Province species, five had their northern distribution limit and four their southern distribution limit between Iquique $\left(20^{\circ} \mathrm{S}\right)$ and Valdivia $\left(40^{\circ} \mathrm{S}\right)$. Another nine species had their southern distribution limit south of Puerto Montt within the fjord region And four had their southern distribution limit close to the Peninsula Taitao.

Of the 35 species of the fjord region, 11 had their northern distribution limit in Puerto Montt $\left(42^{\circ} \mathrm{S}\right)$, nine north of Puerto Montt, and two had deep-water records off northern Chile. In the North Patagonian Zone, 12 of the species can be found in the inner fjords (two restricted to these) and 24 around the exposed islands (11 restricted to the more exposed areas). In the Central Patagonian Zone, seven species can be found in the inner fjords and 16 in the channels.

\section{DISCUSSION}

\section{Results from the literature}

Looking at the data from the literature (Figs. 1a y 1b), no zoogeographic limits are recognizable along the Chilean coast. The Magellanic Province (42 species) shows greater diversity than the Peruvian Province (36 species). Within the Magellanic Province, the North Patagonian Zone is inhabited by the most species (31). This reflects the extensive higher sampling effort close to Puerto Montt $\left(42^{\circ} \mathrm{S}\right)$ due to the numerous collection sites of the Lund University Chile Expedition in the Golfo de Ancud (1948-49). A higher sampling effort can again be observed in the Straits of Magellan. Nevertheless, the observed distribution patterns of the Chilean sea anemone species show a strong deficit in data. During the large vessel-based expeditions, most sampling was carried out off Coquimbo, Valparaíso, Concepción, Puerto Montt, and Punta Arenas, mainly in the intertidal and deeper waters. Sampling sites between these cities are rare. The most serious sampling deficit lies in the Chilean fjord region. This region is formed by two mountain ranges, the high Andes and the coastal mountain range; the valleys of the latter range are partially submerged south of Puerto Montt, forming countless islands and fjords. Due to the highly structured morphology, the coastline is increased by a factor of 60, totalling nearly 90000 $\mathrm{km}$ (map scale). This hardly accessible area with harsh weather conditions holds a high amount of different habitats from protected fjords to channels and exposed coast. Although recent expeditions to this region took place (Joint Magellan "Victor Hensen" Campaign 1994, CIMAR Fiordos expedition, 1995-present), no papers about the sea anemones collected during these trips have been published so far. The distribution data from Sebens \& Paine (1979) were not included in this analysis because if and how species were sampled or identified was not comprehensible (in their collection, only the most common species were given name tags; only a few species originated from the fjord region). Within the fjord region, the shallow-water fauna of the rocky subtidal, especially the more exposed areas, has been sampled least of all since it can only be examined by Scuba diving and with ROVs. 


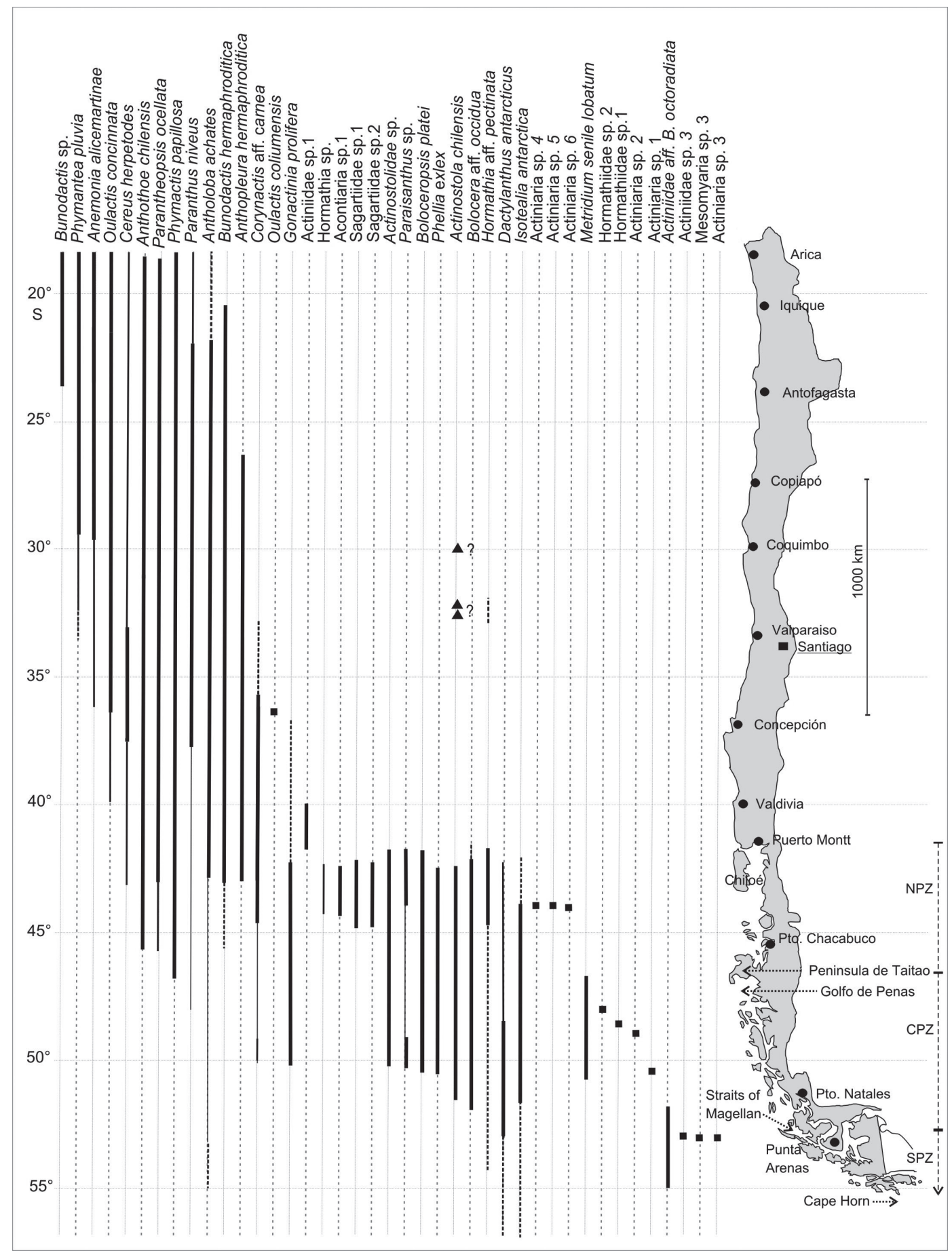

Figure 2. Distribution map of 41 shallow-water Chilean sea anemones collected by Günter Försterra and the author. Line thickness shows species abundance (thick and medium lines); thin lines connect sampling sites that lie far apart; interrupted lines indicate records of other authors; "?" uncertain record. NPZ: North Patagonian Zone, CPZ: Central Patagonian Zone, SPZ: South Patagonian Zone.

Figura 2. Mapa de distribución de 41 especies de anémonas chilenas de aguas someras recolectadas por Günter Försterra y la autora. El grosor de las líneas indica abundancia (línea gruesa y mediana), líneas delgadas conectan sitios de recolección muy alejados; línea interrumpida: registros de otros autores, "?”: registro dudoso. NPZ: Zona Patagónica Norte, CPZ: Zona Patagónica Central, SPZ: Zona Patagónica Sur. 


\section{Results from own sampling}

\section{The northern and central Chilean coast}

Only four of the northern Chilean shallow-water sea anemones found in this study have distribution ranges within the limits of the Peruvian Province (Fig. 2); their southern distribution limits are spread over more than $1000 \mathrm{~km}$. Most of the species found off northern and central Chile extend clearly south of Puerto Montt into the fjord region (Fig. 2). The observed pattern fails to indicate either the existence of a sea anemone fauna that is characteristic of the Peruvian Province or a transitional zone north of Puerto Montt. Thus, the pattern contradicts the classical hypothesis of a general faunal break at $42^{\circ} \mathrm{S}$ (Brattström \& Johanssen, 1983; Camus, 2001). Rather, a gradual replacement of warm water species through cold water species can be observed along the coast, as is also known for polychaetes (Montiel et al., 2004, 2005).

\section{The fjord region}

\section{Eurybathy or deep-water emergence}

Eurybathy or deep-water emergence is an interesting phenomenon in which species that are generally found in deeper waters appear in relatively shallow fjord waters. This phenomenon is also known from other fjords, e.g. in New Zealand (Grange et al., 1981) and Norway. We found several of these deepwater species (e.g. Actinostola chilensis, Isotealia antarctica, Bolocera occidua) in the Central Patagonian Zone, in even shallower water than in the North Patagonian Zone. This observation was confirmed by species of other invertebrate taxa (e.g. the gastropod Acesta patagonica and probably also the hydrocoral Errina antarctica). When reaching farther north along the exposed Chilean coast, at least part of the Patagonian cold-water fauna (e.g. the corals Desmophyllum dianthus, Caryophyllia huinayensis, and Tethocyathus endesa, and the gastropod Acesta patagonica) is displaced to greater depths, where it can be found at several hundred $m$ depth, e.g. off Concepción (e.g. Schrödl, 2003; Cairns et al., 2005) or off Coquimbo (Doumenc, 1984, e.g. Hormathia pectinata, Actinostola chilensis); in these cases, the fauna is overlain by northern warm water fauna.

\section{The North Patagonian Zone (Puerto Montt to Peninsula Taitao)}

The northern part of the fjord region, the North Pa- tagonian Zone, is inhabited by the highest number of shallow water sea anemones (27). Within this area, the channels and exposed islands show higher diversity ( 24 species) than the inner fjords (12 species). This diversity distribution is probably due to the low salinity layer in the fjords that, in combination with the tidal amplitude, is responsible for relatively low diversity in the intertidal and shallow water (0-15 $\mathrm{m})$. It might also influence larvae that depend on the upper water layers. Within a fjord, diversity diminishes from the mouth to the head.

In summary, one can say that the species we observed in the shallow waters of the northern fjord region belong to three different faunal elements: a) shallow water species that are clearly restricted to fjord- and channel-specific habitats; b) representatives of a deep-water emergence (eurybathy) fauna characteristic of the shallow waters of northern Chilean fjords but that can also be found in deeper waters further north; and c) the fauna of the exposed coast, more common in the outer channels and around the outer islands than in the inner fjords and extending further north along the Chilean coast. The first faunal element (restricted to fjord-specific habitats) has a clear-cut northern distribution limit due to the abrupt change in coastal morphology and, consequently, a lack of suitable habitats further north. This confirms the hypothesis of Riemann-Zürneck (1986) and Brattström \& Johanssen (1983) that the South Chilean fauna possess a high percentage of endemic species. The coexistence and merging of the three faunistic elements mentioned above is provoked by an abrupt diversification of coastal morphology south of $42^{\circ} \mathrm{S}$ due to the splitting up of the straight coastline into numerous channels and fjords. This results in an increased number of species and thus characterizes the fjord region as a biodiversity hotspot (see also Fernández et al., 2000).

\section{The Central Patagonian Zone (Peninsula Taitao to Straits of Magellan)}

South of the Peninsula Taitao $\left(46-47^{\circ} \mathrm{S}\right)$, glaciers and melt water from the Southern Patagonian Icefield strongly influence the hydrographic conditions (Pickard, 1973); the fiords of this region is characterized by low salinities and high sedimentation (Pickard, 1973). The high stress due to sedimentations might be the reason for the relatively low biodiversity (Thatje \& Mutschke, 1999), not only for sea anemones (own observation), in the inner fjords (seven species). In the channels and islands where the influence 
of glacial sediment was not noticeable anymore, we found very diverse benthic communities with a more southern Magellanic character, distributed very patchily, including 19 sea anemone species. Although we also found 14 of these 19 species in the North Patagonian Zone, their dominances differed strongly in each area. The most common shallow water species of the northern inner fjords, Anthothoe chilensis that is densely covering mytilid banks, was replaced by Metridium senile lobatum. This latter species was by far the most common species in the Central Patagonian Zone, reaching as far north as the Golfo de Penas and covering large areas. The species Metridium senile lobatum does not inhabit the fjords north of Peninsula Taitao where Anthothoe chilensis seems to have found its taken the same niche.

\section{The South Patagonian Zone (Straits of Magellan to Cape Horn)}

We found only eight species in the South Patagonian Zone, most probably due to a lower sampling effort, and e.g. we found no species in the area around Puerto Natales, which is strongly influenced by glacial sediment. In Fuerte Bulnes, south of Punta Arenas, we only sampled at one site and examined the intertidal of two sites.

\section{CONCLUSIONS}

The Chilean actinofauna is still very poorly known. Of the 63 Chilean species, $19(30 \%)$ are of uncertain taxonomic status, $36(57 \%)$ were only reported once for Chile, and $19(30 \%)$ have only once been sampled. Nineteen $(30 \%)$ of the described species were collected in water deeper than $50 \mathrm{~m}$. The literature mainly reflects a sampling effort and does not allow further zoogeographical conclusions. Based on our own collections, the highest biodiversity of shallowwater sea anemones can be found in the northern part of the fjord region ( $66 \%$ of the 41 collected species), and within this region in the more exposed (western) areas. However, population densities of sea anemones within the fjords are at least as high as in the more exposed areas. The observed distribution pattern contradicts the classical hypothesis of a general faunal break at $42^{\circ} \mathrm{S}$, suggesting instead a gradual replacement of warm water species through cold water species along the coast. It still remains to be clarified whether the Peninsula Taitao represents a major zoogeographic barrier. The species limited to fjord habitats have their northern distribution limit at $42^{\circ} \mathrm{S}$ due to the lack of adequate habitats further north. In the fjords, deep-water emergence adds deep-water species to the shallow water fauna. This phenomenon seems to be more pronounced in the Central and South Patagonian Zone than in the North Patagonian Zone. The area with the highest sampling deficit is the Patagonian fjord region and, within this region, especially the more exposed areas.

\section{ACKNOWLEDGEMENTS}

I am particularly grateful to Günter Försterra for his company and great help during the field trips. The expeditions to the Central Chilean Zone were supported by the PADI Foundation, the CONAF (Corporación Nacional Forestal de Chile), the Centro Aclimatización Zoológica (CAZ), and NAVIMAG. Many thanks to all of them. This is publication number 7 of the Huinay Scientific Field Station.

\section{REFERENCES}

Brace, R.C. 1981. Intraspecific aggression in the colour morphs of the anemone Phymactis clematis from Chile. Mar. Biol., 64: 85-93.

Brattström, H. \& A. Johanssen. 1983. Ecological and regional zoogeography of the marine benthic fauna of Chile. Report $\mathrm{N}^{\circ} 49$ of the Lund University Chile Expedition 1948-49. Sarsia, 68: 289-339.

Cairns, S., V. Häussermann \& G. Försterra. 2005. A review of the Scleractinia (Cnidaria: Anthozoa) of Chile, with the description of two new species. Zootaxa, 1018: 15-46.

Camus, P.A. 2001. Biogeografía marina de Chile continental. Rev. Chil. Hist. Nat., 74: 587-617.

Carlgren, O. 1899 (for 1898). Zoantharien. Hamb. Magelh. Sammelr., 4: 1-48.

Carlgren, O. 1927. Actiniaria and Zoantharia. In: T. Odhner (ed.). Further Zool. Res. Swed. Antar. Exped. 1901-1903. P.A. Norstedt \& Söner, Stockholm, pp. 1-102.

Carlgren, O. 1959. Reports of the Lund University Chile Expedition 1948-49 38. Corallimorpharia and Actiniaria with description of a new genus and species from Peru. Lunds Univers. Årsskr. N. F. Avd. 2, 56: 1-39.

Carter, D.V. 1965. Actinias de Montemar, Valparaíso. Rev. Biol. Mar., Valparaíso, 12: 129-160. 
Dana, J.D. 1846. Zoophytes. United States Exploring Expedition. During the years 1838, 1839, 1840, 1841, 1842. Under the command of Charles Wilkes, U.S.N. Lea and Blanchard, Philadelphia, 740.

Dayton, P.K., K.W. England \& E.A. Robson. 1995. An unusual sea anemone, Dactylanthus antarcticus (Clubb, 1908) (Order Ptychodactiaria), on gorgonians in Chilean fjords. In: J.C. den Hartog (ed.). 6th International Conference on Coelenterate Biology, National Natuurhistorisch Museum, Leiden, pp. 135-142.

Doumenc, D. 1984. Les actinies bathyales du Chili: un exemple d'utilisation de fichiers informatiques. Ann. Inst. Océanogr., 60: 143-162.

Fautin, D.G. 2003. Hexacorallians of the world: sea anemones, corals and their allies. [http://hercules. kgs.ku.edu/hexacoral/anemone2/index.cfm]. Revised: 2.6.2006

Fernández, M., E. Jaramillo, P.A. Marquet, C.A. Moreno, S.A. Navarrete, F.P. Ojeda, C.R. Valdovinos, \& J.A. Vásquez. 2000. Diversity, dynamics and biogeography of Chilean benthic nearshore ecosystems: an overview and guidelines for conservation. Rev. Chil. Hist. Nat., 73: 797-830.

Försterra, G. \& V. Häussermann. 2003. First report on large scleractinian (Cnidaria: Anthozoa) accumulations in cold-temperate shallow water of south Chilean fjords. Zool. Verh., Leiden, 345: 117-128.

Grange, K.R., R.J. Singleton, J.R. Richardson, P.J. Hill \& W.d.L. Main. 1981. Shallow rock-wall biological associations of some southern fjords of New Zealand. N. Z. J. Zool., 8: 209-227.

Häussermann, V. 2003. Redescription of Oulactis concinnata (Drayton in Dana, 1846) (Cnidaria: Anthozoa), an actiniid sea anemone from Chile and Perú with special fighting tentacles; with a preliminary revision of the genera with a "frond-like" marginal ruff. Zool. Verh., Leiden, 345: 173-207.

Häussermann, V. 2004a. Identification and taxonomy of soft-bodied hexacorals exemplified by Chilean sea anemones; including guidelines for sampling, preservation and examination. J. Mar. Biol. Ass. UK, 84: 931-936.

Häussermann, V. 2004b. Redescription of Phymactis papillosa (Lesson, 1830) and Phymanthea pluvia (Drayton in Dana, 1846) (Cnidaria: Anthozoa), two actiniid sea anemones from the south east Pacific with a discussion of the genera Phymactis, Bunodosoma and Phymanthea. Zool. Meded., Leiden, 78: 345-381.
Häussermann, V. 2004c. The sea anemone genus Actinostola Verrill 1883: variability and utility of traditional taxonomic features, and a re-description of Actinostola chilensis McMurrich 1904. Polar Biol., 28: 26-38 (Erratum 2005: 338-350).

Häussermann, V. \& G. Försterra. 2001. A new species of sea anemone from Chile, Anemonia alicemartinae n. sp. (Cnidaria: Anthozoa). An invader or an indicator for environmental change in shallow water? Org. Divers. Evol., 1: 211-224.

Häussermann, V. \& G. Försterra. 2003. First evidence for coloniality in sea anemones. Mar. Ecol. Progr. Ser., 257: 291-294.

Häussermann, V. \& G. Försterra. 2005. Distribution patterns of Chilean shallow-water sea anemones (Cnidaria: Anthozoa: Actiniaria, Corallimorpharia); with a discussion of the taxonomic and zoogeographic relationships between the actinofauna of the South East Pacific, the South West Atlantic and Antarctica. In: W.E. Arntz, G.A. Lovrich \& S. Thatje (eds.). The Magellan-Antarctic connection: links and frontiers at high southern latitudes, Sci. Mar., 69(Suppl. 2): 91-102.

Hertwig, R. 1882. Die Actinien der Challengerexpedition. Gustav Fischer, Jena, 149 pp.

Lancellotti, D.A. \& J.A. Vásquez. 1999. Biogeographical patterns of benthic macroinvertebrates in the Southeastern Pacific Litoral. J. Biogeogr., 26: 1001-1006.

Lesson, M. 1830. Chapitre XVI. Description des animaux de la famille des Actiniées. Voyage autour du monde, exécuté par ordre du Roi, sur la corvette de la Majesté, La Coquille, pendant les années 1822, 1823,1824 , et 1825 , sous le ministère et conformément aux instructions de S.E.M. de Marquis de Clermont-Tonnerre, ministre de la marine. Arthus Bertrand, Paris, pp. 67-83.

McMurrich, J.P. 1893. Scientific results of explorations by the U. S. Fish Commission Steamer Albatross. No. XXIII. Report on the Actiniae collected by the United States Fish Commission Steamer Albatross during the winter of 1887-1888. Proc. US Nat. Mus., 16: 119-216.

McMurrich, J. P. 1904. The Actiniae of the Plate Collection. Zool. Jahrb., 6(Suppl.): 215-306.

Montiel, A., D. Gerdes \& W. Arntz. 2005. Distributional patterns of shallow-water polychaetes in the Magellan region: a zoogeographical and ecological synopsis. In: W.E. Arntz, G.A. Lovrich \& S. Thatje 
(eds.). The Magellan-Antarctic connection: links and frontiers at high southern latitudes. Sci. Mar., 69(Suppl. 2): 123-133.

Montiel, A., C. Ríos, E. Mutschke \& N. Rozbaczylo. 2004. Poliquetos de fiordos y canales adyacentes al Campo de Hielo Patagónico Sur, Chile (Annelida: Polychaeta). Cienc. Tecnol. Mar, 27: 49-67.

Pickard, G.L. 1973. Water structure in Chilean fjords. In: R. Fraser (ed.). Oceanography of the South Pacific. New Zealand National Commission for UNESCO, Wellington, pp. 95-104.

Riemann-Zürneck, K. 1986. Zur Biogeographie des Südwestatlantik mit besonderer Berücksichtigung der Seeanemonen (Coelenterata: Actiniaria). Helgol. wiss. Meeres., 40: 91-149.

Riemann-Zürneck, K. \& V.A. Gallardo. 1990. A new species of sea anemone (Saccactis coliumensis $\mathrm{n}$. sp.) living under hypoxic conditions on the central Chilean shelf. Helgol. wiss. Meeres., 44: 445-457.

Schrödl, M. 2003. Sea slugs of southern South America. Conch Books, Bad Kreuznach, 165 pp.

Sebens, K.P. \& R.T. Paine. 1979. Proceedings of the International Symposium on Marine Biogeography and Evolution in the Southern Hemisphere, Bioge- ography of anthozoans along the west coast of South America: habitat, disturbance, and prey availability. N.Z. DSIR Inf. Ser. 137. Auckland, pp. 219-238.

Stotz, W.B. 1979. Functional morphology and zonation of three species of sea anemones from rocky shores in southern Chile. Mar. Biol., 50: 181-188.

Stuardo, J. \& C. Valdovinos. 1992. Barreras, límites faunísticos y provincias biogeoquímicas en Sudamérica austral. In: V.A. Gallardo, O. Ferretti, \& H.I. Moyano G. (eds.). Oceanografía en Antártida. Centro EULA, Universidad de Concepción, Concepción, pp. 443-451.

Thatje, S. \& E. Mutschke. 1999. Distribution of abundance, biomass, production and productivity of macrozoobenthos in the sub-Antarctic Magellan Province (South America). Polar Biol., 22: 31-37.

Viviani, C.A. 1979. Ecografía del litoral chileno. Stud. Neotrop. Fauna Environ., 14: 65-123.

Zamponi, M.O. \& A.C. Excoffon. 1992 (1995). La anemonofauna de Bahía Concepción (Chile). I. Algunos aportes a la distribución y biología de los géneros Phlyctenactis Stuckey, 1909 (Actiniaria: Actiniidae) y Antholoba Hertwig, 1882 (Actiniaria: Actinostolidae). Physis, Sec. A, 50(118-119): 1-6. 